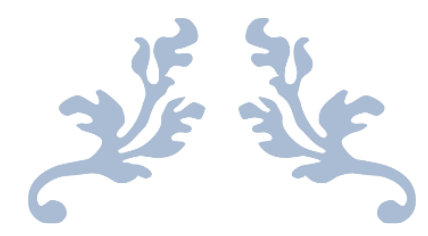

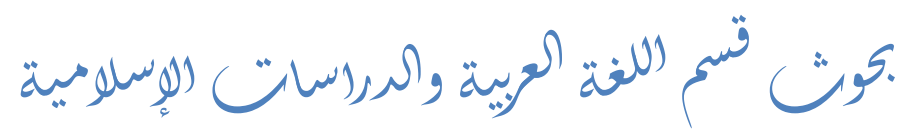

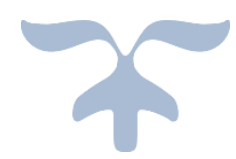




\section{الحذف ودوره الدلالي في شعر ابن مطروح}

الباحث / محمد عبد الحليم عثمان

\section{الملخص:}

هذا بحث بعنوان " الحذف ودوره الدلالي في شعر ابن مطروح " وهو مستخلص من رسالة الدكتوراه التي عنواها: " بناء الجملة بين ابن مطروح وابن سناء الملك ".

حيث تتخذ هذه الدراسة النص الشعري في ديوان ابن مطروح مجالا للدراسة النحوية، لما

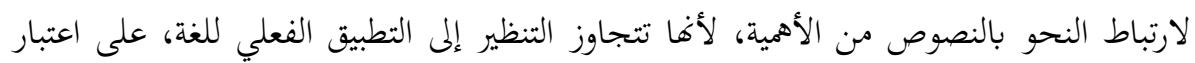

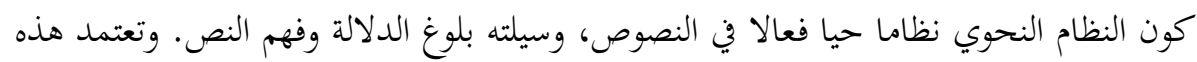

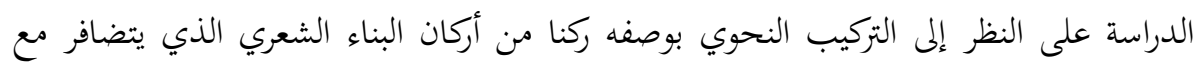

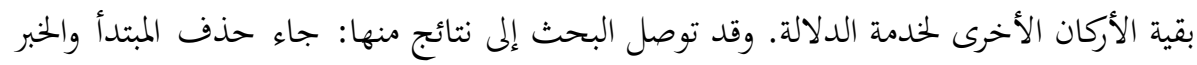

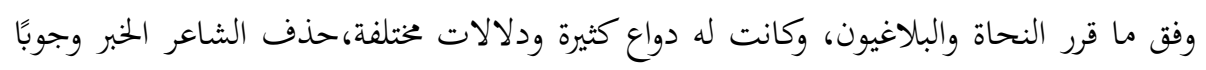

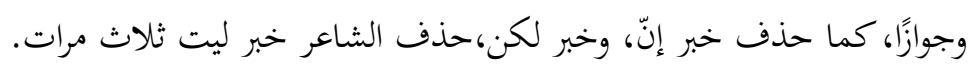

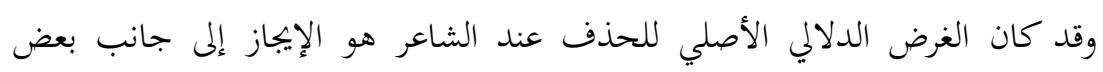

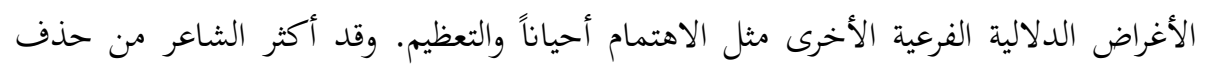

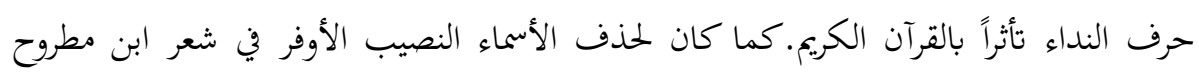

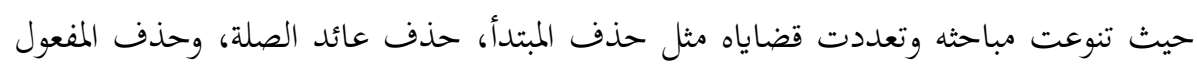

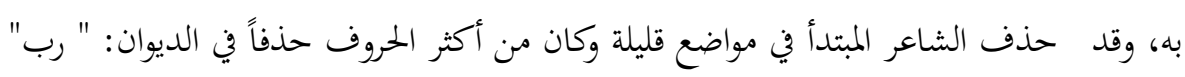

\section{Summary}

This is a research entitled "Deletion and its semantic role in Ibn Matrouh's poetry." It is extracted from his $\mathrm{PhD}$ thesis entitled: "The Syntax between Ibn Matrouh and Ibn Sana alMalik." 
This study employs the poetic text of Ibn Matruh for grammatical purposes. The significant correlation between syntax and text transcends the boundary of theorization into the realm of practical application as far as the Arabic language is concerned.

This research addresses the linguistic features of ellipsis and insertion in his poetry and their denotative aspects. The Chapter covers noun phrase ellipsis (NPE), verb phrase ellipsis (VPE), the omission of articles, the omission of sentences and the insertion. In this research the researcher concludes, among other things, that the poet repeatedly opt to the omissions of vocative articles and noun phrase ellipsis in addition to the repeated insertion of articles. By employing this linguistic device, the poet aims at achieving the rhetorical feature of brevity, in addition to other features such as emphasis and showing significance.

$$
\begin{aligned}
& \text { أحمد الله سبحانه على أن جعلنا من أمة خير بني أرسل، وأنزل علينا الكتاب الذي ا يَّتِيهِ }
\end{aligned}
$$

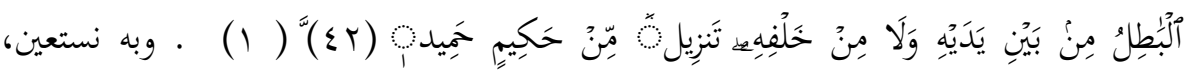

$$
\begin{aligned}
& \text { والصلاة والسلام على أشرف المرسلين، سيدنا محمد وعلى لمعنى آله وصحبه وسلم }
\end{aligned}
$$

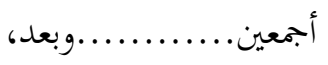

$$
\begin{aligned}
& \text { فهذا بحث بعنوان " الحذف ودوره الدلالي في شعر ابن مطروح " وهو مستخلص من } \\
& \text { رسالة الدكتوراه التي عنواها: " بناء الجملة بين ابن مطروح وابن سناء الملك ". }
\end{aligned}
$$


حيث تتخذ هذه الدراسة النص الشعري في ديوان ابن مطروح مجالا للدراسة النحوية؛ حيث تعتمد هذه الدراسة على النظر إلى التركيب النحوي بوصفه ركنا من أركان البناء الشعري الذي يتضافر مع بقية الأركان الأخرى للدمة الدلالة.

أسباب اختيار الموضوع: واختياري لدراسة شعر ابن مطروح يرجع لعدة أسباب منها: 1. مكانة الشاعر وأهمية شعره، واشتماله على العديد من الأغراض الشعرية، كالغزل، والمدح، والفخر، والحكمة، والرثاء، والوصف، والهجاء. r. قلة الدراسات النحوية التي تناولت شعر ابن مطروح ·

r. رَصْدُ مواضع الحذف في شعر ابن مطروح، لمعرفة كيفية استخدامه للغة، وإلى أي مدى تخضع هذه المواضع لقواعد اللغة كما حددها علماء النحو والبلاغة.

$$
\text { - رصداف اللدراسة: سعى البحث إلى تحقيق بعض الأهداف وهي: }
$$

- دراسة الحذف من خلال شعر الشاعر، بوصفه نصا لغويا من النصوص الحديثة نسبياً.

$$
\text { - بيان دلالات الحذف في شعر الشاعر. }
$$

وتقتضي طبيعة هذا البحث أن يأتي في مقدمة وأربعة مباحث:

المقدمة:أذكر فيها نبذة عن الموضوع والمنهج المتبع في تحليل الجملة ثم أهداف البحث

$$
\text { وأسباب اختيار الموضوع والدراسات السابقة. }
$$

$$
\text { التمهيد: أترجم فيه للشاعر، وأتحدث عن مادة البحث. }
$$

المبحث الثاني: حذف الأفعال.

المبحث الرابع: حذف الجمل
المبحث الأول: حذف الأسماء.

المبحث الثالث: حذف الحروف 


$$
\text { الخاتمة:وتشمل النتائج التي توصل إليها البحث }
$$

منهج البحث: يعتمد البحث على المنهج الوصفي التحليلي، الذي يقوم على استخراج

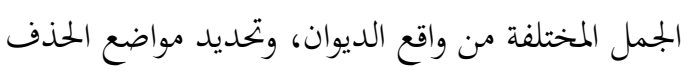

وقد اعتمدت في دراستي هذه على نص ديوان ابن مطروح ، تحقيق ودراسة د/ حسين

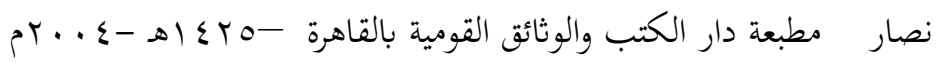

الدراسات السابقة: يستفيد البحث من الدراسات التي قدمت في بناء الجملة

- بناء الجملة في شعر إبراهيم ناجي دراسة نفي التركيب والدلالة،ماجستير للباحث أحمد محمد طنطاوي، كلية الآداب بجامعة القاهرة.

- بناء الجملة في شعر ابن سنان الخفاجي دراسة نخوية دلالية، دكتوراة للباحث عبد الله محمد مصباح الجعكي، كلية دار العلوم بجامعة القاهرة.

\section{ترجمة الشاعر: ابن مَطْرُوح (ץ)}

مولده: أبو الحسن يهيى بن عيسى بن إبراهيم بن الحسين بن علي بن حمزة بن إبراهيم بن

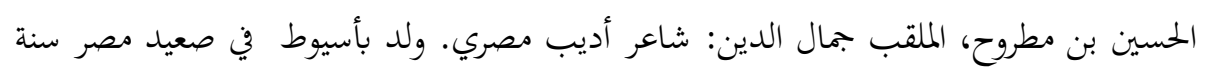

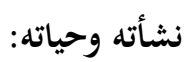

ونشأ بأسيوط وأقام بقوص مدة، وتنقلت به الأحوال في الخدم والولايات، ثم اتصل

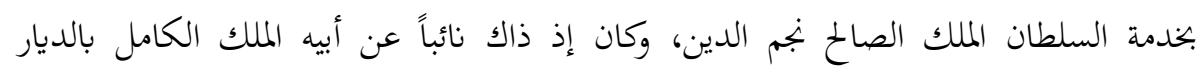

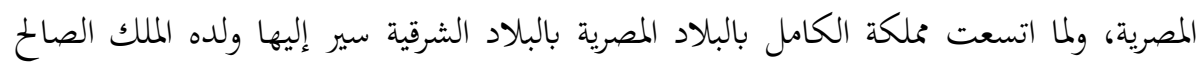

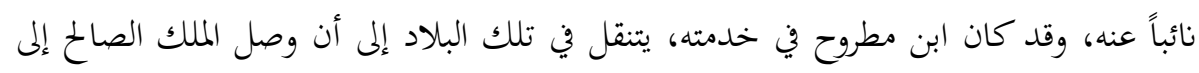

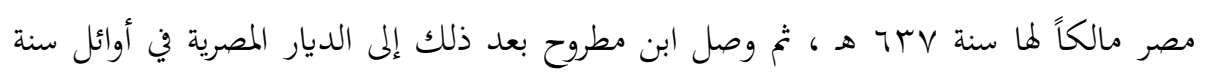

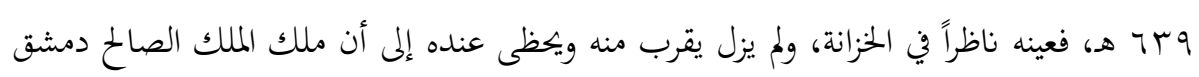


سنة ب §ج ه، وقد رتب لدمشق نواباً، فكان ابن مطروح في صورة وزير لها، ومضى إليها وحسنت

حالته وارتفعت منزلته. (r) حسن (r)

غير أن دوام الحال من المحال؛ فقد تغير عليه الملك الصالح لأمور نقمها عليه وعزله عن

ولايته بدمشق، ولما مات الملك الصالح ليلة النصف من شعبان سنة V乏 T هـ بالمنصورة عاد ابن مطروح إلى

مصر. (§) يقول سبط ابن الجوزي: " ولما وصل توران شاه إلى ديار مصر أعرض عنه

بالكُلِّة فأقام خاملاً إلى أن مات فعاد إلى مصر ". (•)

\section{ثقافته:}

لما كانت قوص دار العلم والأدب والشعر حينذاك، فقد اختلف إلى ما بها من

حلقات العلماء والأدباء، وفيها تعرف على البهاء زهير وكان يكبره بنحو عشر سنوات، وأعجب به البهاء، فاتخذه رفيقًا وصديقًا، واستمع إلى أشعاره وملكته الشعرية تتفتح فكان يشجعه، وكان سببًا في إلحاقه بديوان الرسائل لابن اللمطي (؟)، وعندما غضب ابن اللمطي على البهاء زهير

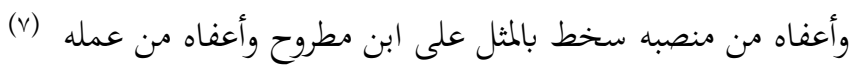

\section{صفاته:}

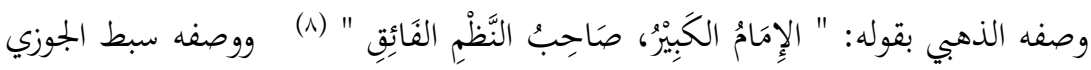

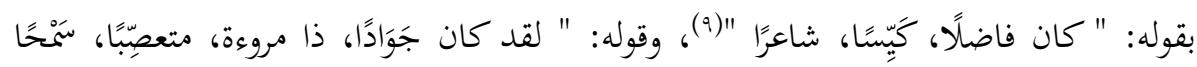

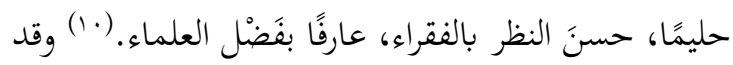
وصفه ابن خلكان بقوله: " وكانت أدواته جميلة وخلاله حميدة، جمع بين الفضل والمروءة

والأخلاق الرضية" (11) (11) 
وقد اختلف المؤرخون في تاريخ وفاته فقد جعل سبط الجوزي الوفاة في شعبان سنة

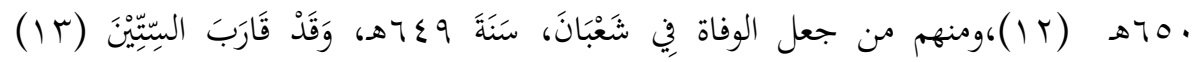
والراجح ما ذهب إليه ابن خلكان لما كان بينهما من علاقة وطيدة ؛ يقول ابن خلكان: " وكان بيني وبينه مودة أكيدة ومكاتبات في الغيبة، وبجالس في الحضرة بتري فيها مذاكرات أدبية لطيفة،

$$
\text { وله ديوان شعر أنشدني أكثره " (ع ابينه موده ومالباه }
$$

ولم يختتف المؤرخون في مكان الوفاة فقد توفي بمصر، وكانت له جِنازة عظيمة

$$
\text { (10) (1 )، ودفن بسفح المقطم (1) }
$$

\section{توطئة}

لا شك أن اللغة العربية لغة الإيجاز، ومن حكم العرب القديمة:( البلاغة الإيجاز )،

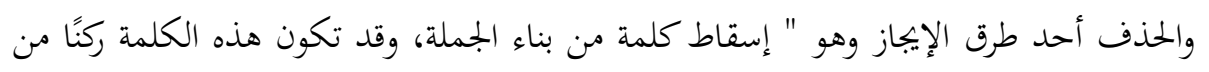
أركاها كالمبتدأ أو الخبر أو الفعل أو الفاعل، وقد تكون حرفا، وقد تحذف الجملة كجملة جواب

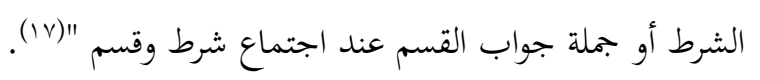

ولقد تحدث النحويون والبلاغيون عن الحذف، فالنحاة تكلموا عن مواطن الجواز والوجوب والامتناع، أما البلاغيون فدرسوا بلاغة الحذف ومزاياه وأغراضه.

$$
\text { ومن أسباب الحذف: }
$$

1 - كثرة الاستعمال:يقول ابن الأنباري: " والحذف في كلامهم لدلالة الحال وكثرة الاستعمال أكثر من أن يكصى"(1) (1)، ويقول سيبويه " وما حُذف في الكلام لكثرة استعمالهم كثير " (1 (1) ) (19)

r - طول الكلام: إذا طال الكلام ثقل، فجاز الحذف طلباً للخفة، وجنوحًا

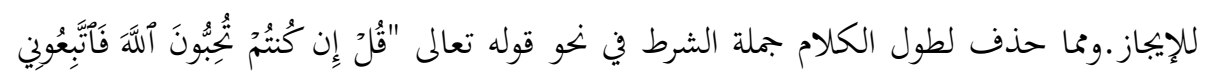

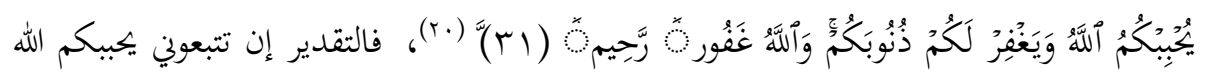
ويغفر لكم ذنوبكم (r) (r) 
ץ - ضرورة الشعر:اختلف النحاة في مفهوم " الضرورة الشعرية "فذهب بعضهم إلى أها

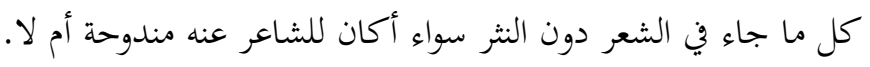

ع - الحذف لأسباب قياسية تركيبية:وهو حذف كلمة أو أكثر من الجملة، أو حذف جملة أو أكثر من الكلام. (rr) .ومن ذلك حذف خبر المبتدأ الواقع بعد " لولا "إذا كان كونًا مطلقًا

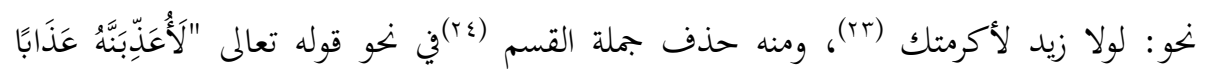

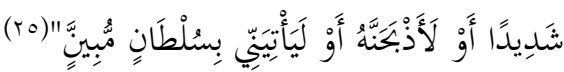

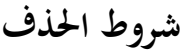

يقول ابن جنى " قد حذفت العرب الجملة والمفرد والحرف والحركة، وليس شيء من ذلك

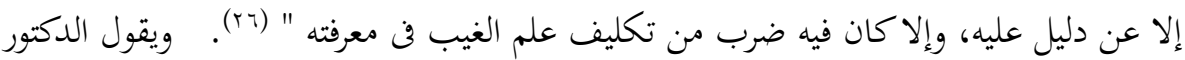

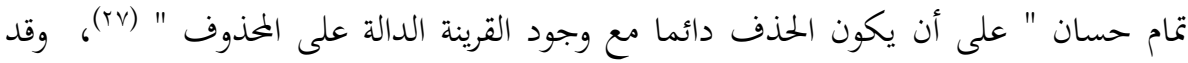
سمى ابن جني الحذف جاعة العربية، وأوضح معنى ذلك السيوطي فقال " لأنه يشجع على الكلام

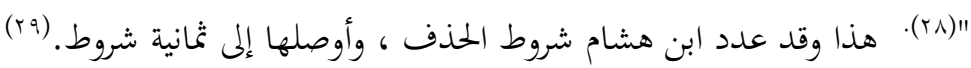

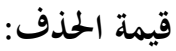

وقد أشار البلاغيون إلى قيمة الحذف، ومزاياه، وأكدوا أن للحذف ثلاثَ مزايا، الأولى:

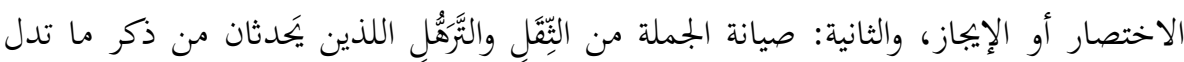

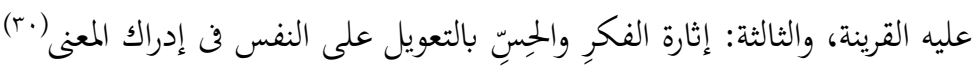

تقدير الحخدوف وتقدير المحذوف إنّما يرجع إلى سببين كما ذكر عبد القاهر الجرجاني، "

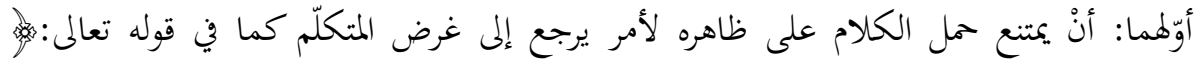

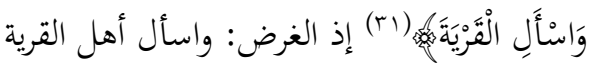

وبما أن الحذف ينقسم إلى واجب وجائز، فإِن المعوَّل عليه في الدراسة البلاغية هو الحذف الجائز فقط؛ لأن المتكلم غُخَيَّر بين ذكر ذاك العنصر وحذفه على حسب ما يقتضيه ويستدعيه

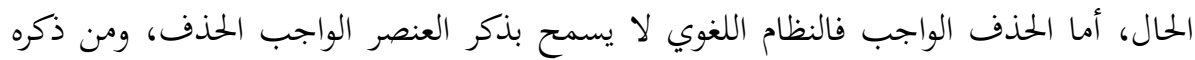


فقد أخطأ في التركيب، فالحذف الواجب إذن مفروض على المتكلم. و ولذلك يري بعض الباحثين

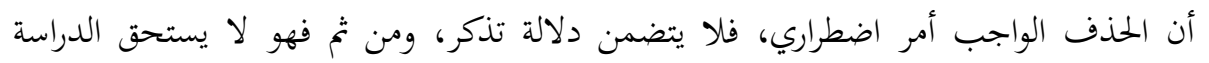

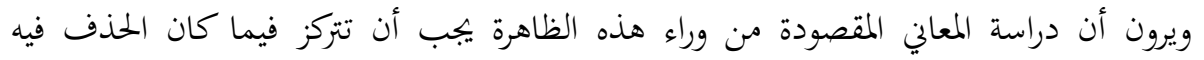

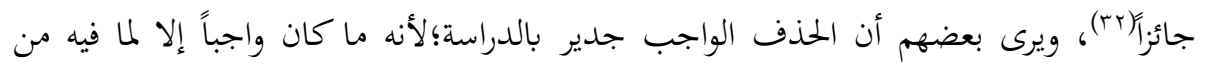

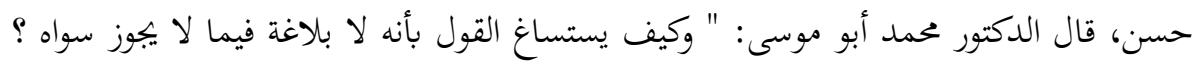

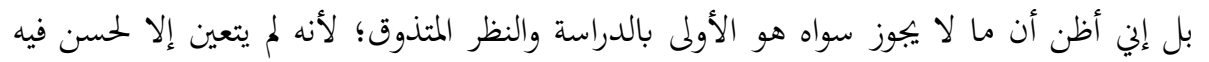

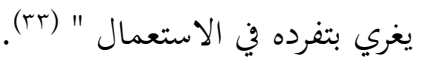

والبحث لا يتفق مع الرأي الثاني؛ لأننا نحم على ما قيل بالفعل، لا ما كان يمكن أن

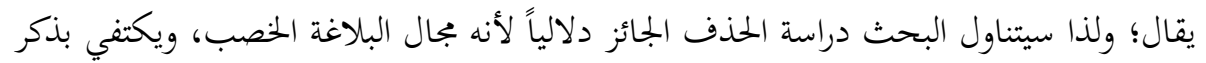
أمثلة على الحذف الواجب. ويمكن تصنيف مواضع الحذف في شعر ابن مطروح كالآتي:

$$
\text { المبحث الأول: حذف الأسماء: - مذاء }
$$

\section{حذف المبتدأ:}

حدد النحاة الحالات التي يحذف فيها المبتدأ وجوبا، وأشهرها أربعة هي (๕):

1 - - إذا كان مخبراً عنه بنعت مقطوع لمدح نحو: الحمد لله أهل المدح. أو ذم نحو مررت بزيد الفاسق. أو ترحم نحو مررت ببكر المسكينُ.

r - - إذا أخبر عنه بمصدر هو بدل من اللفظ بفعله نحو: سمعٌ وطاعةٌ، أي: أمري سمعِّ. r- - إذا أخبر عنه بمخصوص في باب نعم، نحو: نعم الرجل زيد أي: هو زيد.

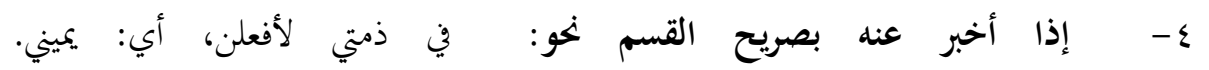
أما الحذف الجائز فهو بجال البلاغة الخصب التَِّى تفتش عن أسراره ودواعيه، وقال النحاة: إن المبتدأ يحذف جوازا في مواضع، ويكثر ذلك في جواب الاستفهام مثل وَمَا

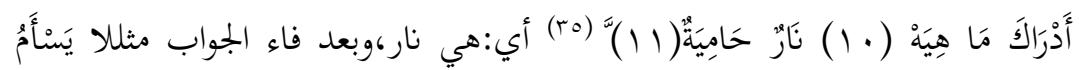

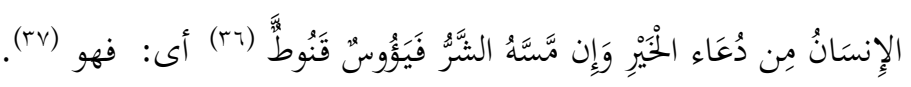


يقول ابن عصفور " والمبتدأ بالنظر إلى الإثبات والحذف قسمان، قسم يلزم فيه إثباته وهو

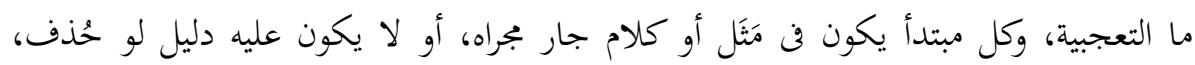

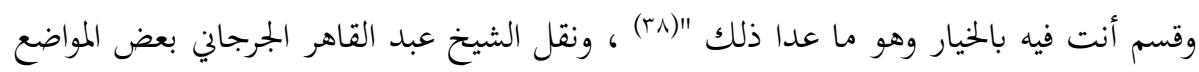

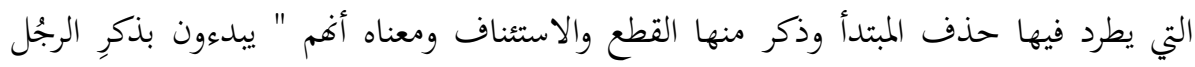

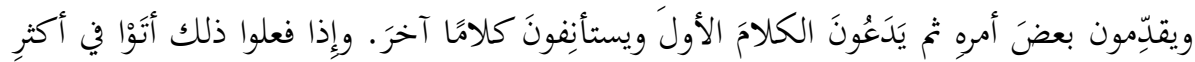

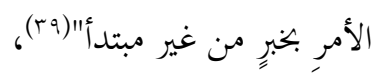

وعند دراسة شعر ابن مطروح نجد حذف المبتدأ جوازاً في أمثلة كثيرة منها: قوله عند

$$
\text { قبر إبراهيم الخنليل، صلوات الله عليه: }
$$

خليلَ الله قدُ جئناكَ نرجو شفاعتك التي ليست تردُ

أنلنا دعوةً واشفع تشفعْ إلى من لا يخيب لديه قصدُ

وقل يا رب: أضيافُ ووفُّ م لهم بمحمد صلةٌ وعهُ

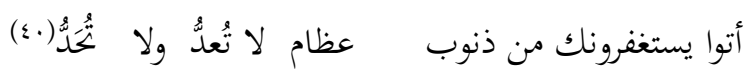

في البيت الثالث حذف المبتدأ من جملة القول والتقدير هؤلاء أضياف، وقد دل عليه السياق ، والغرض من الحذف هنا الاهتمام بالخبر والتركيز عليه.وهذا من الحذف الجائز كما

ويكثر حذف المبتدأ جوازا في القطع والاستئناف " كما تقدم من كلام عبد القاهر

$$
\text { الجرجاني "، وبعد الفاء الداخلة على جواب الشرط: }
$$

سقى المنازل بالجرعاء من إضم وساكن الرمل منهل من الديم

ومر في جانب الوعساء منبجسا على المعالم بين البان والعلم

منازل ضل قلبي في مراتعهـ مع الجآذر بين الضال والعنم (1) 
في البيت الثالث حذف المبتدأ والتقدير: هي منازل، ودل على ذلك السياق حيث تحدث

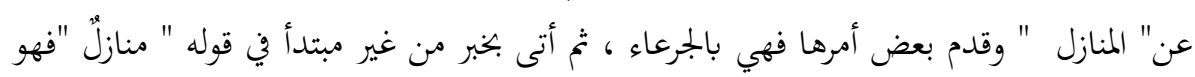

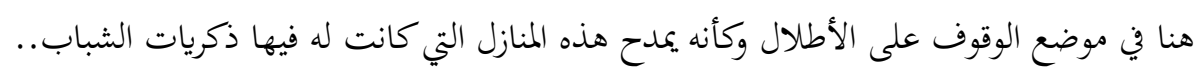
حذف الحبر:يحذف الحبر وجوباً في مواضع أشهرها: -

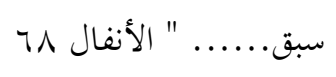

- - - م إذا كان المبتدأ نصًا في القسم مثل قول الشاعر:

$$
\text { إذا رضيت على بنو قشير لعمر الله أعجبني رضاها (זء) }
$$

- - وإذا كان المبتدأ مصدرًا، وبعده حال سدت مسد الخبر (r) مثل: مساعدتي الرجل محتاجاً، أي إذ كان محتاجاً.

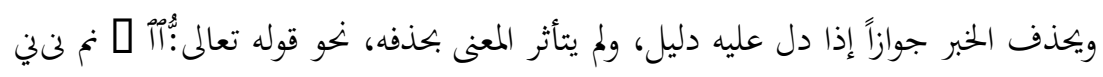

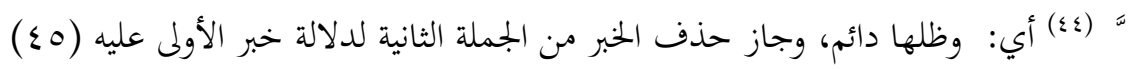

$$
\text { ومن نماذج حذف الخبر في شعر ابن مطروح: }
$$

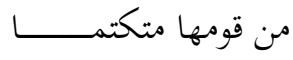
لما طرقت خبـــــــــــاءها

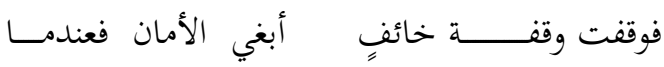

قالت:عليـك ولا تخف من أسرتي مطر السمـا قلت :القرى قـالت: أبح تلك كل ما يموي الحمى

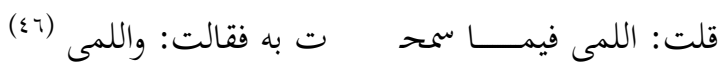


في هذه الأبيات حوار بين الشاعر ومحبوبته يبدو فيه تأثره بعمر بن أبي ربيعة، وفي الحوار يكثر الحذف، والذي يهمنا هنا الحذف في البيت الأخير حيث حذف الخبر في قوله: واللمى والتقدير: واللمى فيما سمحت؛ وذلك للإيجاز ولأنه مفهوم من السياق.

$$
\text { وقوله يمدح فخر الدين بن شيخ الشيوخ: }
$$

من معشرٍ ترى العِدى خبرَ العُلا عنهم وتسنده إلى الحسادٍ

ضربت على كرة الأثير خيامهم حيث النجوم بها من الأوتادٍ

وببدتُ هناك وجوهُهم وأكفهم قد كُنّقتْ ببوارقٍ وعهادِ

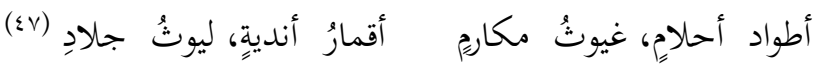

فقد حذف الأخبار في البيت الأخير والتقدير: لهم أطواد أحلام، ولهم غيوث مكارم، ولهم أقمار أندية ، ولمم ليوث جلاد، والحذف هنا جائز؛ لأنه دل عليه دليل، وقد حذف للإيجاز

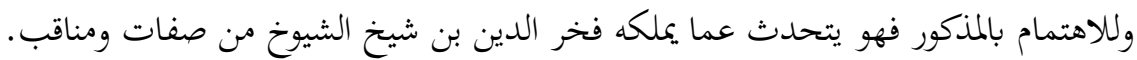

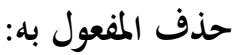

ا. يحذف المفعول به اقتصارًا، واختصارًا: فالأول: حذف المفعول به اقتصاراً: عندما تقتصر نسبة الفعل إلى الفاعل (^ء) وبذلك يكون الفعل المتعدي كاللازم، ولا ينبغي أن

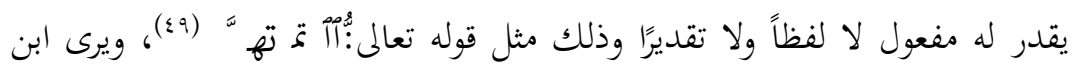
هشام أن هذا " لا يسمى محذوفاً لأن الفعل ينزل لهذا القصد منزلة ما لا مفعول له.

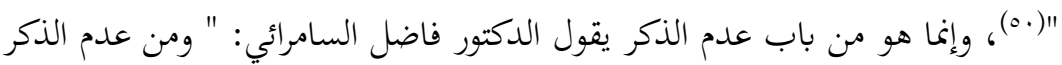

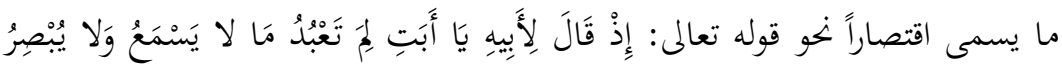
وَلا يُغْنِي عَنكَ شَيًًْا (10) فهذا ليس من باب الحذف لأنه ليس القصد تعلق السمع والبصر بمفعول معين ولكن القصد لِمِ تعبد ما لا يتصف بصفة السمع والبصر ؟، 
فليس لهذين الفعلين مفعول به في التقدير فهذا من باب عدم الذكر وليس من باب الحذف "(م)

ومن أمثلة ذلك في شعر ابن مطروح:قوله إلى فخر الدين بن قاضي دارا: أصبحت تُعطِى والأراذلُ تمنعُ أوسعتَنا جودًا ولؤمًا أوسعُوا إنِّ أغارُ على المناصبِ أن يُرى مَنْ لا يليقُ بها يضرُ وينفعُ (ro) فالشاعر هنا يتحدث إلى فخر الدين مقارناً بينه وبين الأراذل الذين وصلوا إلى مناصب لا

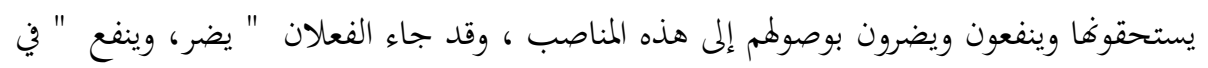
البيت الثاني دون المفعول به.

1. والثاني:حذف المفعول به اختصارا: وذلك عندما يحذف وهو مراد ملحوظ، فيكون حذفه للتخفيف، وذلك مثل قوله تعالى: قَالَ سَآوِي إِلَّل جَبَّل يَعْصِمْنِي مِنَ الْمَاء قَالَ

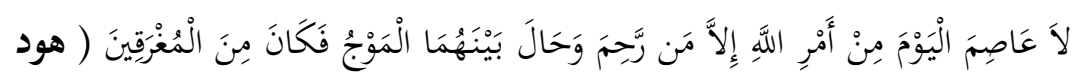

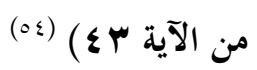

$$
\text { و - منع المواضع التي حذف فيها المفعول به اختصارًا في شعر ابن مطروح: }
$$

ا. يحذف المفعول كثيراً في هذه المواضع لدلالة ما بعده عليه، كقوله تعالى: يَكَادُ الْبَرَقُ

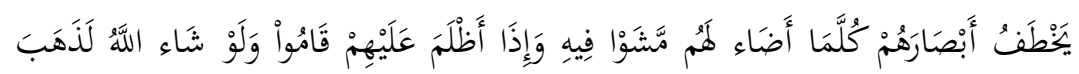

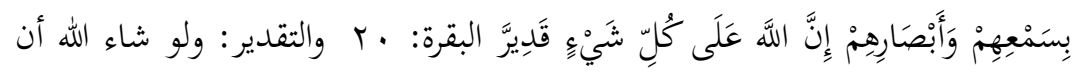

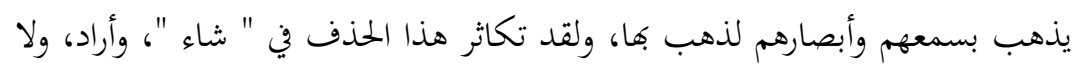

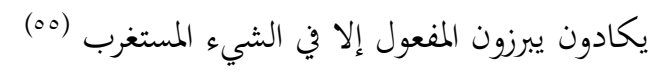
وذلك مثل قول ابن مطروح: 


$$
\text { وقل مات إذات أغريب فأي }
$$

حذف ابن مطروح هنا المفعول به للفعل شاء، والتقدير: شاء أن يقضي، وقد حذفه

$$
\text { اختصاراً بعداً عن التكرار. }
$$

\section{Y - عائد جملة الصلة:}

يكثر حذف الضمير العائد على الاسم الموصول الواقع مفعولا به في جملة الصلة، ومنه

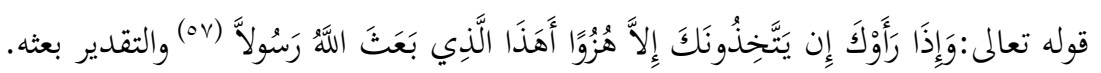

$$
\text { ومن أمثلة ذلك في شعر ابن مطروح قوله: }
$$

$$
\text { إن كنت تقبل من نصيحٍ ينصح }
$$

أذن ولا أمسى ببال يسنح (ه)
في ظله للائذين فلذ به

$$
\text { ما لا رأت عينٌ ولا سمعت به }
$$

في هذه الأبيات حذف المفعول به للفعل رأت وهو ضمير الربط العائد على الاسم الموصول، والتقدير: رأته وقد حذفه لطول الكلام ووجود دليل مقالي عليه.

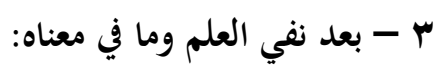

ومن المواضع التي يطرد فيها حذف المفعول به، المفعول به لأفعال العلم والدراية والإبصار

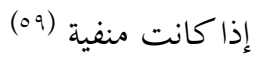

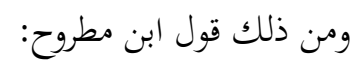

وماذا الذي يجدي وسالمك الردى عليك تلافف في هواك ولا تدري (.7)

$$
\text { حذف الشاعر المفعول به لفعل الدراية المنفي والتقدير: ولا تدري ذلك. }
$$




\section{حذف المضاف}

يجذف المضاف كثيرًا، يقول ابن جني: " وقد حذف المضاف, وذلك كثير واسع"(11)

$$
\text { ومن المواضع التي حذف فيها ابن مطروح المضاف قوله: }
$$

وأعيذ جسمك بعدها من وعكةٍ بعتاده بالذاريات وصاد

وفداك كل العالمين وكل ما فوق الثرى من طارفٍ وتلاد (ri)

حذف ابن مطروح هنا المضاف في قوله " بالذاريات ، وصاد " والتقدير سورة الذاريات،

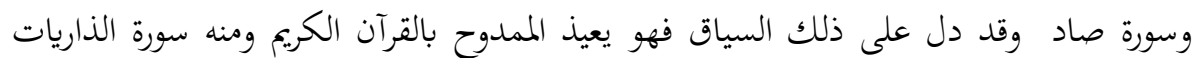
وسورة صاد.

\section{حذف المضاف إليه}

1. يقول السيوطي: " حذف المضاف إليه يكثر في ياء المتكلم نحوقَالَ رَبِّ اغْفْرِ لِي وَلَأَخِي

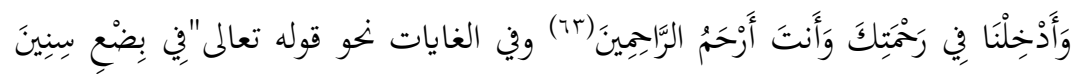

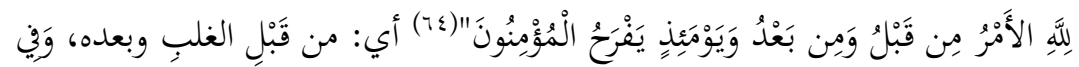

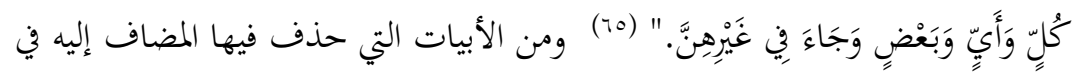

$$
\text { شعر ابن مطروح قوله: }
$$

ودعاؤه في ليله و وهاره يا رب من سطوات موسى نجنى (Ti)

حذف المضاف إليه في الشطر الثاني من قوله: يا رب، فهو يمدح أخاه الملك الأشرف

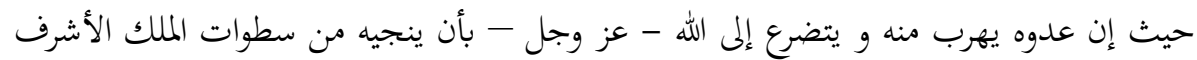
موسى.

وقوله: وإذا هويت ولم يرقَّ من الضنى لك في الصبابة قلبُ كل حسودٍ

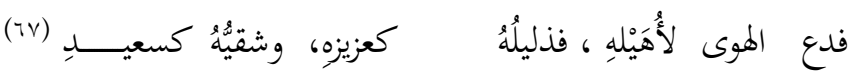


حذف ابن مطروح المضاف إليه في آخر البيت الثاني والتقدير: كسعيده، وقد دل على ذلك دليل مقالي قبله.

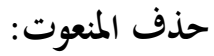

يكثر حذف المنعوت في الشعر والنثر وهذا ما ذهب إليه ابن مالك في البيت الذي ورد في

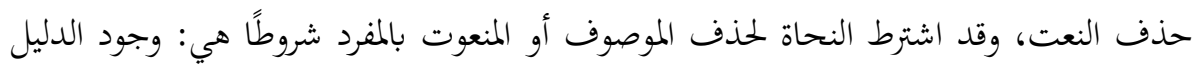

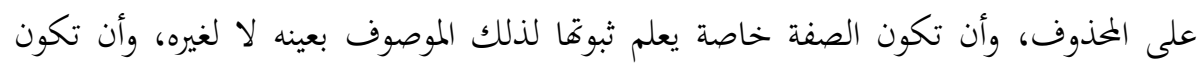

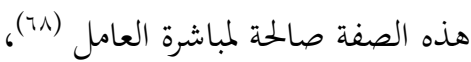

ومن المواضع التي حذف فيها الموصوف عند ابن مطروح قوله يمدح عماد الدين بن شيخ

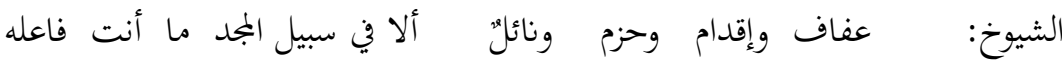

$$
\text { إذا سار فوق الراسيات تزعزعت وصدعت السبع الشداد صواهله (79) }
$$

حذف الموصوف من الشطر الأول في البيت الثاني والتقدير: الجبال الراسيات ، وحذف الموصوف أيضًا من الشطر الثاني والتقدير: السماوات السبع؛ وذلك ليدل على قوته وعزمه وقوة جيشه.وقد توفرت الشروط التي حددها النحاة لحذف الموصوف.

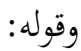

أترضى بأن أُمْسِى أسيرَ أسيرةٍ محصنةٍ أوْ منْ وراءٍ جدارِ

ومن يبتغي عندَ الغواني مودةً كمن يبتغي أخذَ الأسيرِ بثارِ

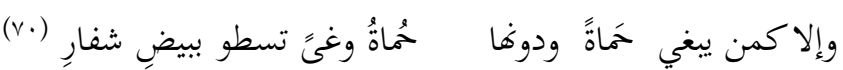

حذف ابن مطروح الموصوف من الشطر البيت الثاني والتقدير: النساء الغواني، كما حذف المنعوت من البيت الثالث والتقدير: بسيوف بيض؛ وذلك ليدل على قوة الممدوح وأنه لا يستطيع أحد أن يأخذ منه شيئًا لا يريد إعطاءه. 


\title{
حذف التمييز
}

يجيوز حذف التمييز إذا وجد عليه دليل وقرينة على المخذوف تحدد مراد المتكلم، أو قصد

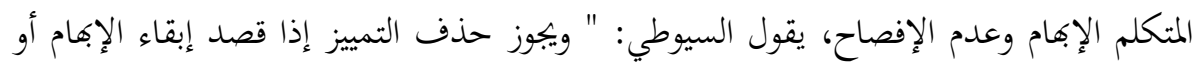

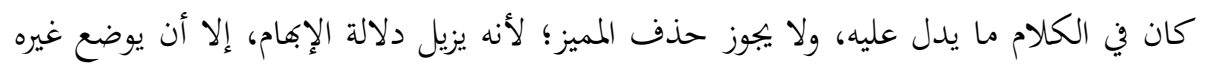
في موضعه، كقوهم: ما رأيت كاليوم رجلاً، وقد يحذف من غير بدل، كقولهم: تالله رجلاً: أي تالله

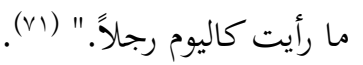
ولم يرد في ديوان ابن مطروح حذف تمييز العدد ولكن ورد حذف تمييز كم، وذلك في قوله يمدح السلطان الناصر صلاح الدين يوسف عند مسيره إلى خلب الخروسة: لا وعينيك ويكفى ذا القسمْ ما رأتْ عينايَ نوماً منذ كم

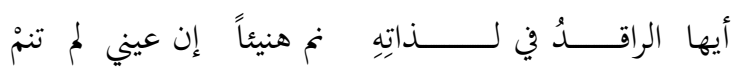
ويح قلبي منْ هوئُ مستهزئُ ما رآني حنقًا إلا ابتسمْ (Vr) والتقدير: كم ليلة أو نحوه؛ وذلك للقافية، وليدل على طول مفارقة النوم لعينه.

\author{
المبحث الثاني: حذف الفعل \\ لحذف الفعل في الجملة صورتان:
}

\section{الصورة الأولى:حذفه وحده وبقاء الفاعل:}

"وذلك أن يكون الفاعل مفصولًا عنه مرفوعًا به, وذلك نحو قولك: أزيد قام, فزيد مرفوع

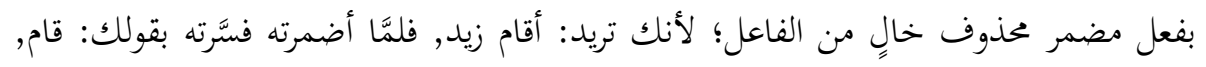
وكذلك:

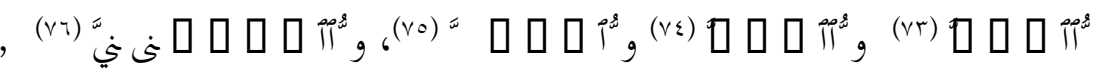
الفعل فيه مضمر وحده. أي: إذا انشقَّت السماء, وإذا كورت الشمس, وإن هلك امرؤ, ولو تملكون "(Yv). ويحذف الفعل جوازاً إذا دل عليه دليل ومن ذلك في شعر ابن مطروح : 


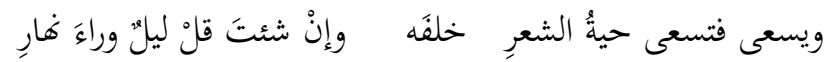

سقى وجنتيه الحسنُ والدمعُ وجنَتِي فيا وردتيه رحمةً لبهاري (V^)

حذف الفعل من البيت الثاني والتقدير: وسقى الدمع وجنتي، وقد دل عليه دليل مقالي وهو ذكره في بداية البيت، وغرض الحذف هنا الإيجاز وعدم التكرار.

ويحذف الفعل حذفاً واجباً إذا فسره فعل آخر يرد بعد الفاعل، ويكون ذلك بعد الأدوات

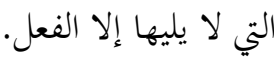

وقد جاء هذا خمس مرات في شعر ابن مطروح أربعٌ منها بعد إذا،وواحدة بعد إِنْ ومن ذلك قله

وكم قائلٍ عندَ وَصْفِي ثناكَ: ألا طرباً بكَ مِنْ هُنْشِد

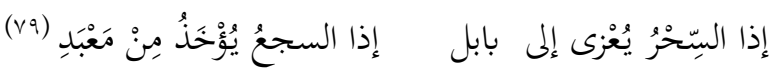

في البيت الثاني حذف الشاعر الفعل بعد إذا، والتقدير: إذا يُعْزى السِّحُرُ يُعْزى، إذا

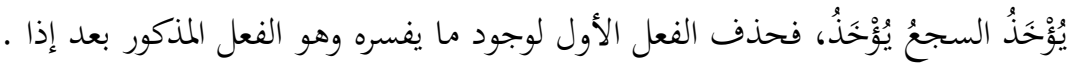

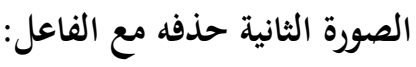

وذلك نهو: زيدًا ضربته؛ لأنك أردت: ضربت زيدًا, فلمَّا أضمرت "ضربت" فسَّرته

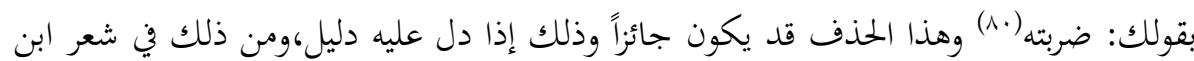

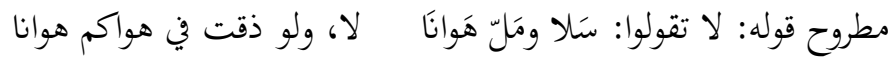
أنا صبُّ، أرىى المذلةَ عزَّام في رضاكم وذنبَكُم غُفْرانا (1) حذف الفعل مع فاعله المضمر من البيت الثاني والتقدير: وأرى ذنبَكُم غُغْرانا، وقد دل عليه دليل مقالي وهو ذكره في الشطر الأول، وغرض الحذف هن الفنا الإيجاز وعدم التكرار. وقوله يمدح الطواشي شمس الدين صواب: 


$$
\begin{aligned}
& \text { ولما تيمَّمناك قــالَ ر رفاقُنا: إلى أين تبغي قلت:خيرَ جنابِ } \\
& \text { وقلتُ لصحبي شرِقُوَا تبلغوا المُنى فغيرُ صوابٍ قصدُ غيرِ صواب (Ar) }
\end{aligned}
$$

حذف الفعل مع فاعله المضمر من البيت الأول والتقدير: أبغي خير جناب، وقد دل عليه السياق، وغرض الحذف هنا الإيجاز وعدم التكرار.

ويحذف الفعل مع فاعله وجوباً مع الإبقاء على جزء من جملته وذلك في مواضع ورد منها في شعر ابن مطروح: - من

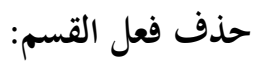

يحذف فعل القسم وجوباً مع الواو والتاء من حروف القسم وذلك لكثرة الاستعمال (rr) وقد ورد القسم باستخدام الباء أربع عشرة مرة (^)،هي ديوان ابن مطروح ومن ذلك قوله: تزيدين عزًا كلما زدتُ ذلةً ولولا الموى ما ذلتِ الأسندُ للعُغْرِ خليليَ بالله اتركاني وصبوتي خليليَ باللهِ ابسطا لي بالعذرِ (^) يقسم ابن مطروح هنا على صاحبيه أن يتركاه وصبوته التي كانت سبيًا في ذلته، وأن

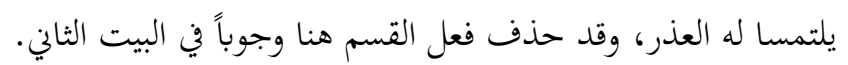
وقد ورد في ديوان ابن مطروح القسم باستخدام الواو ثماني مرات (ז^ومن ذلك قوله:

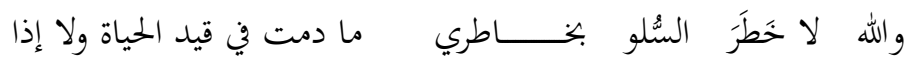

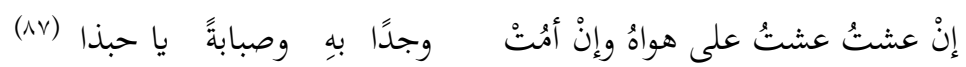
في هذا البيت يقسم أنه لم يخطر السلوان على خاطره ما دام حيًا، وإذا مات فسيكون من صبابته ووجده، وقد حذف فعل القسم هنا وجوباً؛ ليؤكد حبه وعدم نسيانه لخحبوبته حيًا ومينًا. وقد ورد حذف التاء مرة واحدة وذلك قوله: 


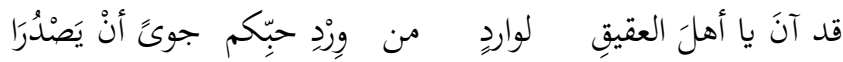

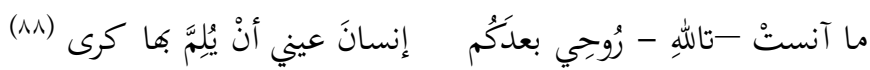

يؤكد ابن مطروح حبه وأنه لا يستطيع النوم ، وقد حذف فعل القسم هنا وجوباً؛ ليؤكد مفارقة النوم عينيه.

\section{حذف الفعل العامل في المصدر}

لا يجوز حذف المصدر المؤكد لعامله،يقول ابن مالك:

$$
\text { وحذف عامل المؤكد امتنع.... وفي سواه لدليل متسع(^a) }
$$

أما إذا كان المصدر غير مؤكد لعامله فالحذف فيه متسع كما قال ابن مالك،ويحذف

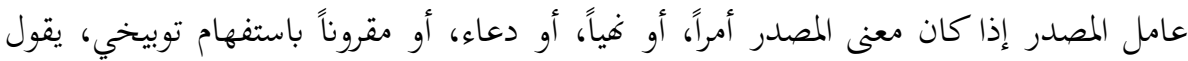

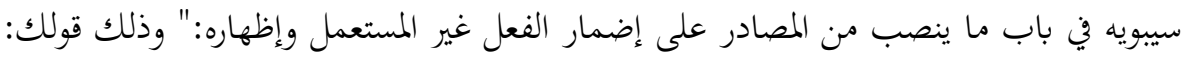

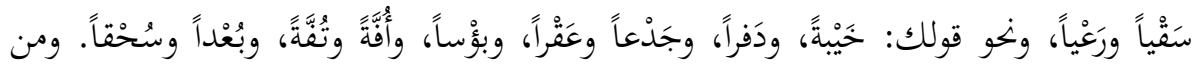

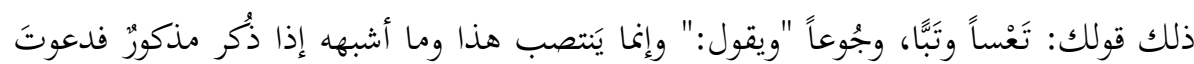

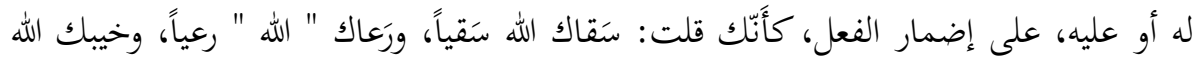

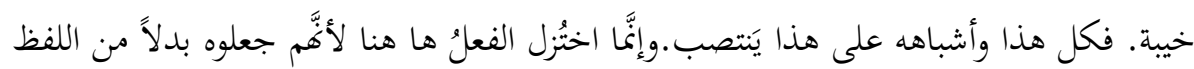

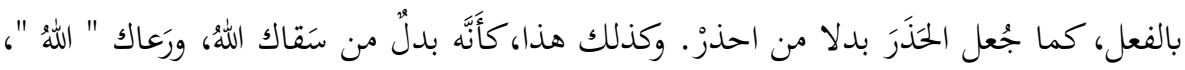

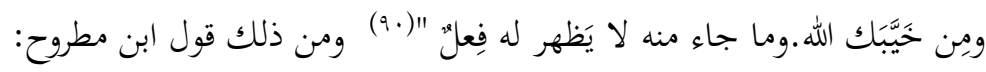

سلاتٌ على ذاك الزمانِ الذي مضى وسقيا لماتيك المعالم والربا (19)

في هذا البيت يدعو لهذا الزمان الذي له فيه ذكريات جميله؛ ويدعو ان يسقي الله هذه الأطلال من - المن

المعالم والربا برحمته، وقد حذف الفعل وأقام المصدر مقامه فكأنه قال: سقى الله سقيًا، وإقامة المصدر مقام الفعل تدل على أن الحدث غير مرتبط بزمن فكأنه يطلب السقيا دائماً. 


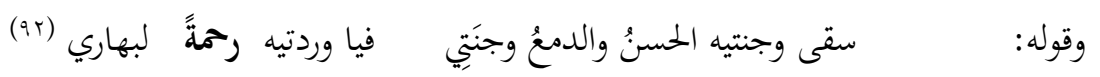
فقد حذف الفعل في عجز البيت وأقام المصدر مقامه فكأنه قال: ارحما وجهي الذي ذبل رحمة تعيد له نضارته.

حذف الفعل في التحذير والإغراء: يحذف الفعل في التحذير وجوبًا إذا كان:

- - بـ " إياك "أو أحد فروعه من ضمائر المخاطبين سواء كان مكررا أو غير مكرر معطوفًا

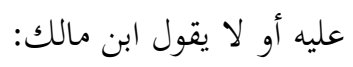

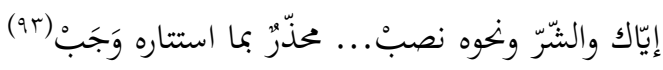
- - بغير " إيا " وفروعه بشرط العطف أو التكرار.

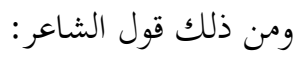
حذارِ سيوفَ الهندِ من أعينِ التركِ فما انْتُضِيَتْ إلا لتؤْذِنَ بالفَتْكِك

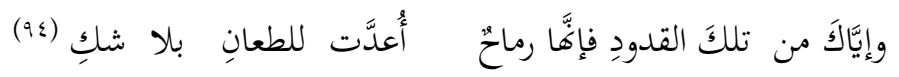
يحذر الشاعر هنا من الاقتراب من هذه القدود، فإذا كالرماح التي أعدت للطعان، وقد

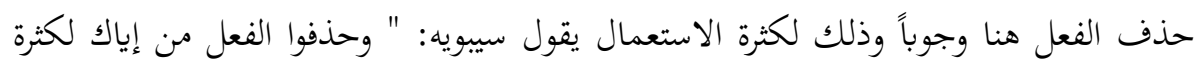

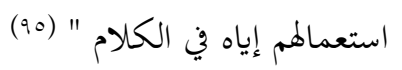
ويحذف جوازًا إذا كان بغير " إيا " ولم يوجد عطف أو تكرار (ج9)، ولم أعثر على نماذج لهذا الحذف عند الشاعر.

وفي الإغراء:يجب حذف الفعل وجوباً إذا كان المغرى به معطوفاً أو مكرراً، وييوز إذا لم

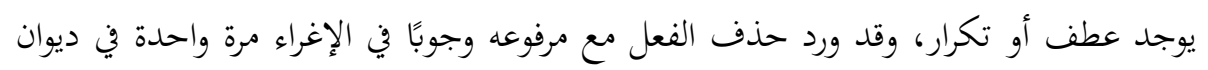

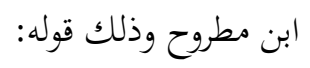


البِدارَ البِدارَ يا ملكَ الأر ضِ وسلطاهَا البدارَ البِدارًا

فدمشقُ الشام وهي عروسُ هيأهما لك السعادةُ دارا

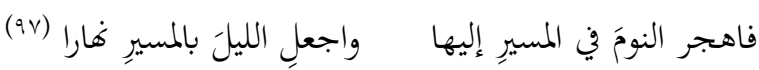

كتب ابن مطروح هذه الأبيات إلى الملك المعظم بن الملك الصالح يدعوه فيها للمسير

ل - ل

وقد جاءت كلمة " البدار " منصوبة بفعل محذوف وجوبًا تقديره الزم؛ فقد جاء المغرى به

مكررًا. وقد حذف الفعل مع فاعله وأبقى على جزء من الجملة وهو المفعول به.

\section{المبحث الثالث: حذف الحروف}

" حذف الحروف ليس بالقياس؛ ذلك أن الحروف إنما دخلت الكلام لضرب من

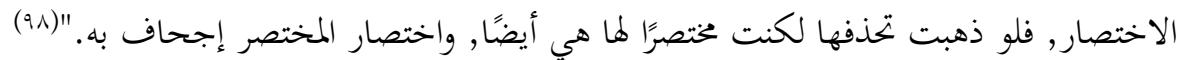

هذا ما قاله ابن جني إلا أن واقع اللغة يخالف ذلك؛فإننا نجد حذف الحروف يقع في مواضع كثيرة ومما جاء في شعري الشاعرين في حذف الحفروف:

\section{-}

تحذف حروف الجر لكثرة الاستعمال يقول سيبويه:" وليس كل جار يضمَر؛ لأن المجرور

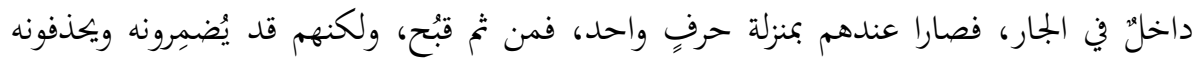

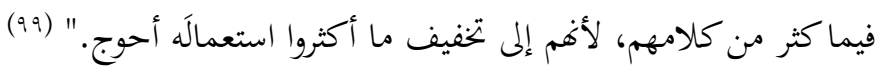
ومن أكثر حروف الجر حذفًا " رب " ويكثر حذفها بعد الواو. 


$$
\text { وقد جاء ذلك كثيراً في شعر ابن مطروح ومن ذلك قوله: }
$$

وقوله: بيضاءَ كالسمراء لينا وقامةً ولم أر غيري شبه البيض بالسمر (1.) فقد حذف الشاعر حرف الجر " رب " بعد الواو في مطلع البيت وبقيت الكلمة بعده

كما يطرد حذف حرف الجر الداخل على " أنْ " الناصبة للمضارع، و " أنَّ " الناسخة،

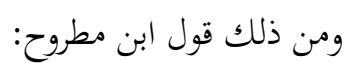

لولا تكذبني قوائم بِيضهم أقسمتُ أنَّ أكنَّهم لمُ تطبقِ

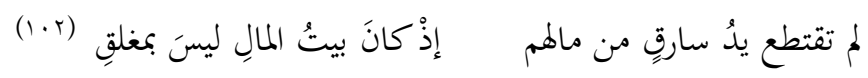

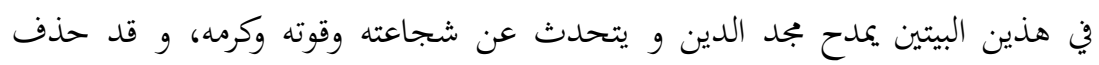

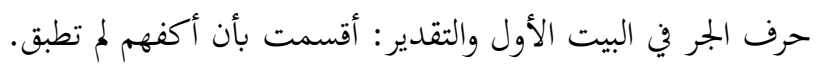

وقد يحذف الجار ويبقى عمله إذا كان معطوفًا على ما تضمن حرفًا مثله ومن ذلك قول ابن مطروح:

$$
\text { ومثل ما بي به ولا عجب هوى بقلبي وقلبه امتزجا (r • ( ) }
$$

فقد حذف حرف الجر:" الباء" من الشطر الثاني والتقدير: وبقلبه، وهو معطوف على قلبي المجرور بالباء.

$$
\text { r }
$$

يحذف حرف النداء كثيرًا وذلك اكتفاء بتضمن المنادى معنى الخطاب، ومن ذلك قول ابن مطروح:

$$
\text { بديع الحسنِ ما هذا التجنيّ ومن أغراكَ بالإعراضِ عنِي (ع.1) }
$$


حذف الشاعر أداة النداء في صدر البيت؛ وذلك ليدل على قرب محبوبته من قلبه

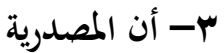

" أنْ "تنصب المضارع ظاهرة، أما مضمرة فيرى البصريون جواز حذفها في ثلاثة مواضع

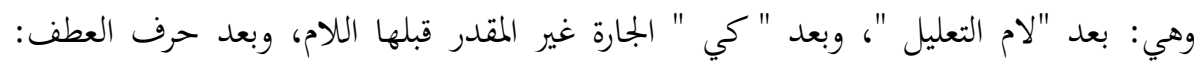

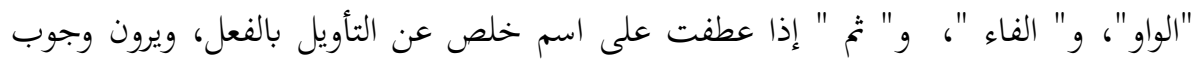

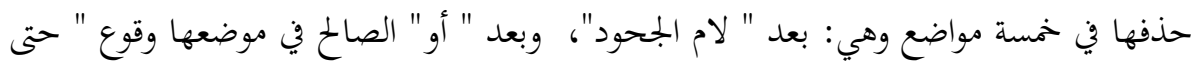

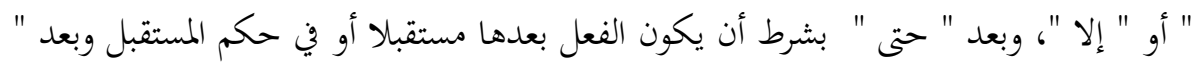
الواو "، أو " الفاء " المجاب عنهما بنفي أو طلب سواء كان الطلب أمراً أو هُيًا أو دعاء

أو استفهامًا، أما الكوفيون فيرون أن تلك الحروف هي الناصبة للمضارع ولا تقدير

$$
\text { عندهم لأنْ (1.0) - (1). (1) }
$$

$$
\text { ومن ذلك في شعر ابن مطروح قوله: }
$$

ولم يبق إلا أن تنيب وترعوى وتعرض عن ليلي وتقر زينبا (؟-1) حذف الشاعر هنا " أن " بعد الواو، وهذا الحذف جائز عند البصريين والتقدير: و أن ترعوي، وأن تعرض، وأن قجر .

\section{ع - - مذف همزة الاستفهام}

يجيوز حذف همزة الاستفهام، ويكون ذلك بدلالة القرائن، ومنها قرينة السياق، سواء

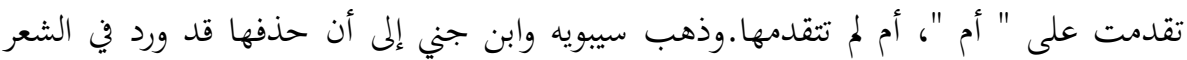

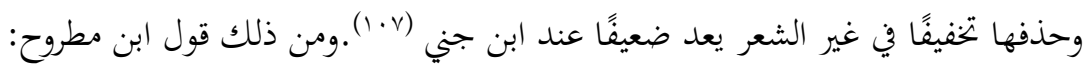

أم جُلَّنــــــــار ووردُ ؟

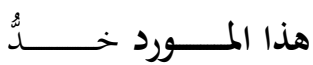

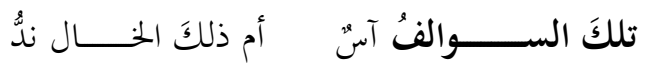

$$
\text { في فيكَ يا بـــرُ راحٍ أم فيه مسك وشهدُ (ه. ) }
$$


في هذه الأبيات حذف الشاعر هزة الاستفهام في قوله: هذا المورد، و: تلك السوالف،

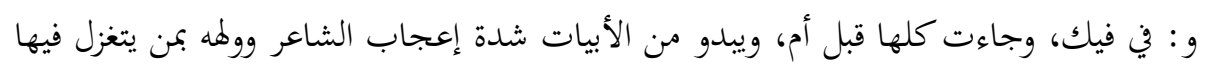
حيث يعدد مظاهر جمالها وقد حذف الهمزة لتركيزه على مواطن جماءلها.

\section{المبحث الرابع: حذف الجمل}

حذف الجملة من الكالام هو أظهر أنواع الحذف، إلا أنه أقل ارتكاباً من حذف

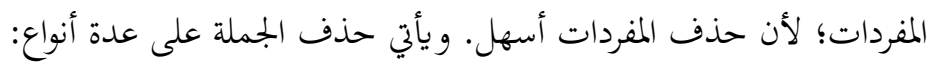

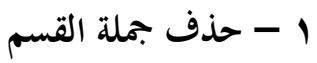

تحذف جملة القسم و أقصد بها فعل القسم وفاعله والمقسم به، ومن أوضح الدلائل

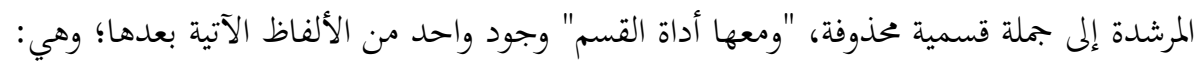

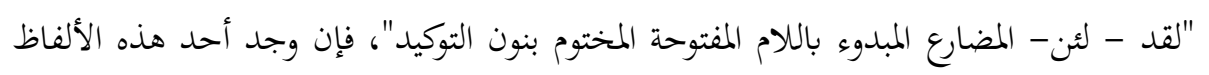

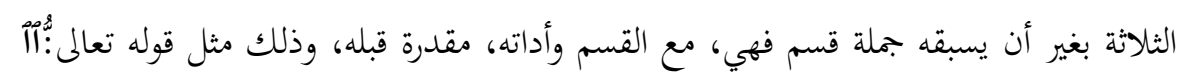
بن بى بيَّ آل عمران: أ أي: أقسم بالله لقد صدقكم الله وعدهـ. وقد حذف ابن مطروح جملة القسم وذلك مثل قوله:

ويسوءني قول العذول لقد سلا لاعشت يوم يمر بي السلوان (9.)

وقوله: مضى وانقضى ذاك الوصال كأنما منام رأته العين طيب وصاله

لقد صد حتى لو تمنيت طيفه لضن على ضعفي بطيف خياله (11) وقوله: ترى هل تعود الدار بتحمع بيننا وترجع أيام الحمى وتعود

لئن رجعت تلك الليالي التي مضت وعاتبتكم إئ إذن لسعيد (III) 
في هذه الأبيات حذف ابن مطروح جملة القسم في قوله: لقد سلا، ولقد صد، وقوله: لئن رجعت تلك الليالي، وقد اعتمد على القرينة اللفظية وهي ذكر جملة الجواب المصدرة باللام وقد في الأولى والثانية ، والمصدرة بـ لئن في الثالثة ، والمصدرة بالمضارع المبدوء باللام المفتوحة المختوم بنون التوكيد في الرابعة. وقد حذف جملة القسم هنا واكتفى بالجواب لأنه لا يحتاج لمزيد من التأكيد للسامع فقد اكتفى بهذه الدرجة من التأكيد.

I. Y - حذف جواب القسم:يجوز حذف جملة جواب القسم إذا دل عليها دليل وذلك

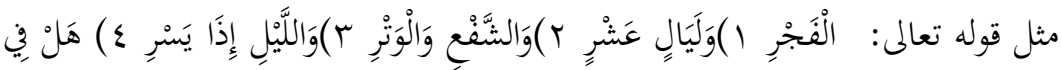
ذَلكَ قَسَمْ لِّنِي حِجْرِ الفجر: 1 -

فجواب القسم هنا محذوف تقديره: ليعذبن (rا'). وقد حذف ابن مطروح جواب القسم ومن ذلك:

سلبوا الكرى عنه فأرسل رائداً في إثرهم من دمعهالمتدفق

ويظل ينشد والرياح تهيجه: بالله يا ريح الصبا هل نلتقي ؟ (ril)

فقد حذف هنا جواب القسم البيت الثاني والتقدير: لتجيبني وقد دل على ذلك الاستفهام: هل نلتقى ؟ فهو يقسم عليه ليجيبه عما سأل عنه؛ وذلك لأنه يتمنى لقاء من يحب.

\section{r - حذف جملة الشرط}

ا. إن حذف جملة الشرط يأتي كثيراً في اللغة العربية، وهو مطرد بعد الطلب نحو ما جاء في

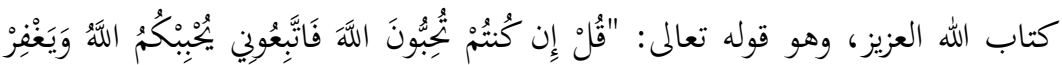

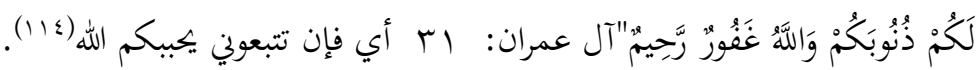
كما يطرد بعد " إن " التي تتبعها لا النافية، وتكون مسبوقة بما يدل على الشرط المخذوف كقول الشاعر: 
فطلقها فلست لها بكفء وإلا يعلُ مفرقك الحسام(110)

$$
\text { ومن أمثلة حذف جملة الشرط في شعر ابن مطروح قوله: }
$$

أغصنَ النَّقا ما أنت عندي شبيهُهُ و وإنْ كنتَ مياسَ المعاطفِ أمْلدا

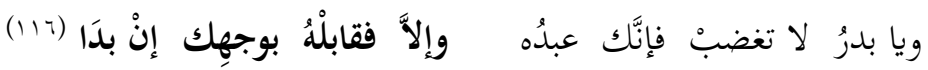

حذف ابن مطروح جملة الشرط في الشطر الثاني من البيت الثاني بعد إن التي تبعتها لا النافية والتقدير: وإن لا ترض بأن تكون عبده فقابله بوجهك، وقد دل على ذلك قرينة السياق في الشطر الأول من البيت، وقد حذفه للإيجاز وعدم التكرار.

$$
\text { ع - حذف جواب الشرط }
$$

"يجوز حذف جواب الشرط والاستغناء بالشرط عنه وذلك عند ما يدل دليل على حذفه نحو أنت ظالم إن فعلت فحذف جواب الشرط لدلالة أنت ظالم عليه والتقدير أنت ظالم إن فعلت فأنت ظالم وهذا كثير في لساهم" (I V ( )

$$
\text { وحذف ابن مطروح جملة جواب الشرط ومثال ذلك: }
$$

وما أنسى ولو نسى التصابي مصاحبة الشباب وإن جفاني (11) حذف الثاعر جواب الشرط والتقدير: وإن جفاني فما أنسى مصاحبة الشباب، وذلك لوجود دليل عليه في أول البيت ولطول الكام.

\section{ع - حذف جملة الصلة:}

تحذف جملة الصلة لوجود قرينة لفظية، مثل من رأيته في المكتبة؟ فتجيب: محمد الذي... أو: سعاد التي... وقد تحذف الصلة من غير أن يكون في الكلام قرينة لفظية تدل عليها وإنما تكون هناك قرينة معنوية يوضحها المقام:كالفخر، والتعظيم، والتحقير، والتهويل... فمن أمثلة الفخر أن يسأل القائد المهزوم البادي عليه وعلى كلامه أثر الهزيمة، قائًا هزمه: من أنت؟ فيجيبه 
المنتصر: أنا الذي... أي: أنا الذي هزمتك. فقد فُهمت الصلة من قرينة خارجية، لا علاقة لها

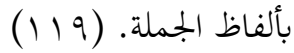
وقد ورد حذف جملة الصلة عند ابن مطروح وذلك قوله: لا سُقَيَت دارُ ولا أهلها ولا ابنُ قاضيها الوقاح البذي ولا رعى الله له ذمة أعنى شهاب الدين ذاك الذي (r.) في هذين البيتين يهجو ابن مطروح ابن قاضي دارا ، وقد حذف جملة الصلة من البيت الثاني؛ وذلك ليدل على التحقير فهو يهجوه والتقدير: الذي يتصف بالوقاحة أو نهوه كما يفهم من البيت السابق.

\section{خاتمة بأهم النتائج}

بعد تلك الرحلة في مواضع الحذف في ديوان ابن مطروح ، يعرض البحث لأبرز النتائج التي توصل إليها على النحو الآتي: ا. . جاء حذف المبتدأ والخبر وفق ما قرر النحاة والبلاغيون، وكانت له دواع كثيرة ودلالات مختلفة. r r . حذف الشاعر الحبر وجوبًا وجوازًا، كما حذف خبر إنّ، وخبر لكنّ. r. حذف الشاعر خبر ليت ثلاث مرات. ع. ورد حذف مفعول المشيئة عند الشاعر عشر مرات فقط. ه. مذف الشاعر الفعل بعد إن الشرطية، وإذا الظرفية المتضمنة معنى الشرط والبميء بالفاعل بعدها مباشرة، فقد ورد ذلك خمس مرات في الديوان. ج. ورد حذف الفعل في القسم عند ابن مطروح ثلاثًا وعشرين مرة. V. أكثر الشاعر من حذف حرف النداء تأثراً بالقرآن الكريع. 
^. كان لحذف الأسماء النصيب الأوفر في شعر ابن مطروح حيث تنوعت مباحثه وتعددت قضاياه مثل حذف المبتدأ، حذف عائد الصلة، وحذف المفعول به. 9 ـ. حذف الشاعر المبتدأ في مواضع قليلة.

• 1 ـ حذف الشاعر الفعل وجوباً في التحذير والإغراء ، ولم يرد حذفه جوازاً. الـمن أكثر الحروف حذفاً في الديوان: " رب ".

rا ـ الغرض الدلالي الأصلي للحذف عند الشاعر هو الإيجاز إلى جانب بعض الأغراض الدلالية الفرعية الأخرى مثل الاهتمام أحياناً والتعظيم. 


\section{الهوامش:}

$$
\text { (') الآية (ب ع) من سورة فصلت }
$$

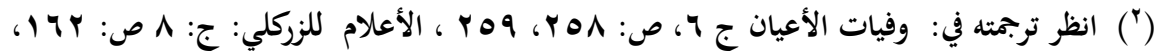

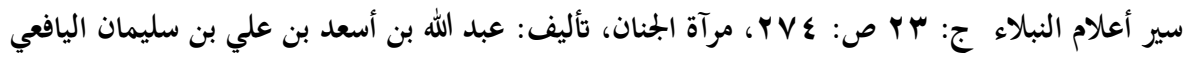

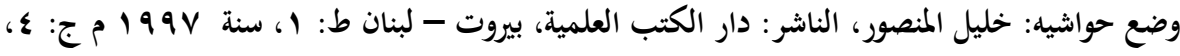

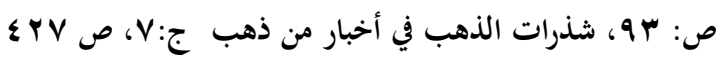

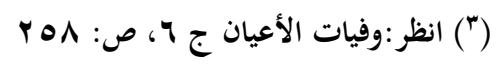

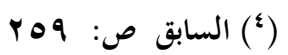

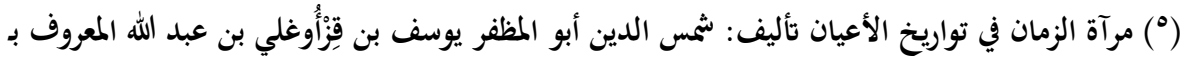

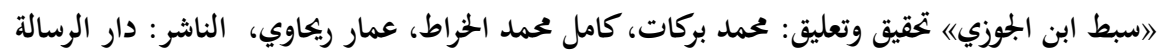

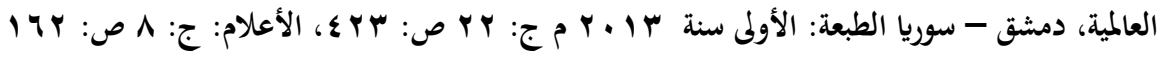

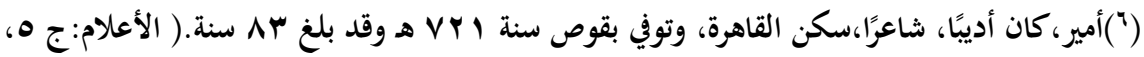

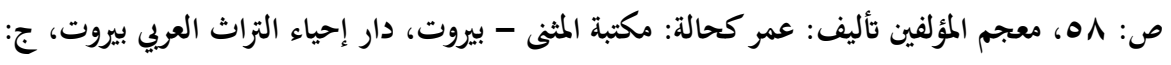

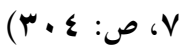

$$
\begin{aligned}
& \text { (") تاريخ الأدب العربي ج: V، ص YN } \\
& \text { (^) سير أعلام النبلاء ج: بr ص: ع عV }
\end{aligned}
$$

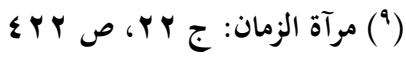

$$
\begin{aligned}
& \text { (• • (1) (السابق ص: rre } \\
& \text { (") وفيات الأعيان ج:7، ص: • "جr } \\
& \text { (ז') مرآة الزمان ج: r }
\end{aligned}
$$

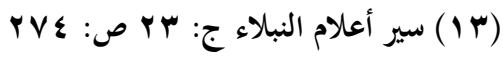




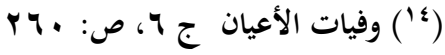

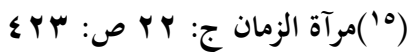

(7" ) ذيل مرآة الزمان تأليف: قطب الدين أبو الفتح موسى بن محمد اليونيني بعناية: وزارة التحقيقات

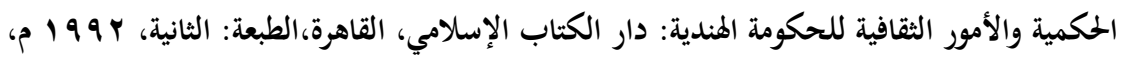

$$
\text { ج: 1) (1) }
$$

(IV) (IV)

$$
\text { 1.. ص P. O }
$$

(^) (الإنصاف فى مسائل الخلاف تأليف أبي البركات بن الأنباري ت ـ د. جودة مبروك، مكتبة الخانجي

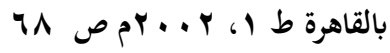

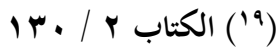

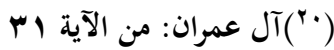

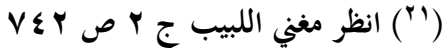

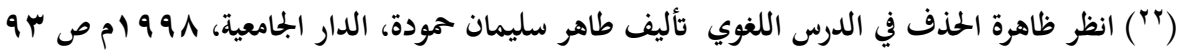

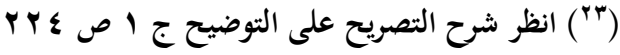

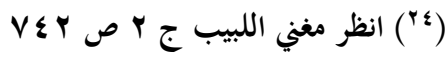

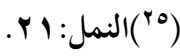

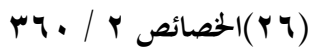

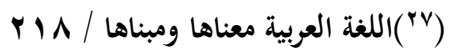

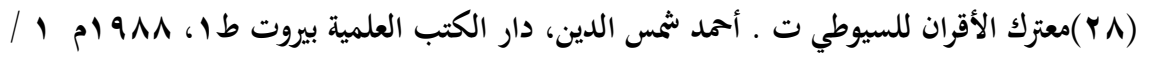
צ

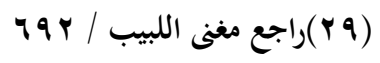




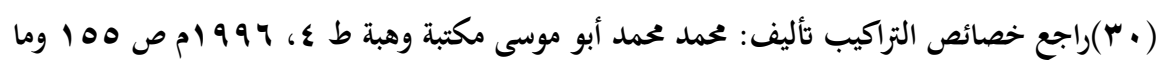

$$
\text { بعدها }
$$

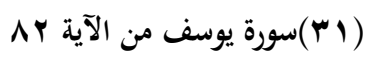

("آّ) انظر البناء النحوي في شعر مانع سعيد العتيبة، بحث مقدم لنيل درجة الدكتوراه إعداد حنان أحمد

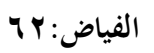

("ب") خصائص التراكيب، دراسة تحليلية لعلم المعاني، تأليف: د. محمد محمد أبو موسى، مكتبة وهبة القاهرة، 10:1919

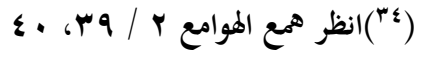

$$
\begin{aligned}
& \text { (") القارعة • 1، 11 } \\
& \text { (") (")فصلت: } 9 \text { ؛ }
\end{aligned}
$$

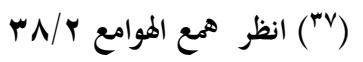

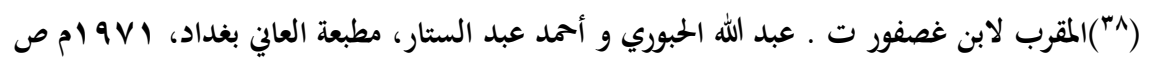
^1

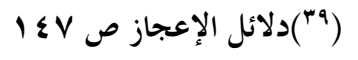

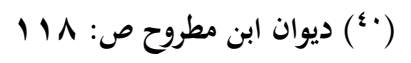

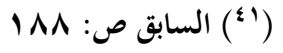

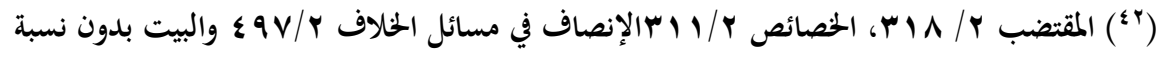

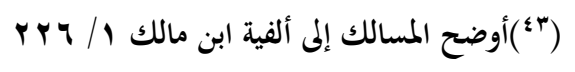

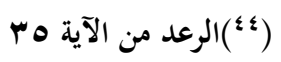

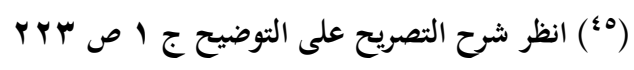




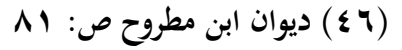

$$
\text { • • }
$$

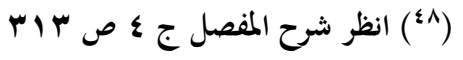

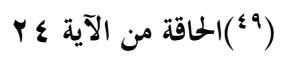

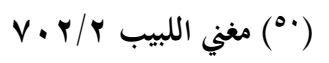

$$
\text { . \& }\{:(01)
$$

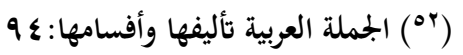

$$
\begin{aligned}
& \text { V^ : ديوان ابن مطروح ص }
\end{aligned}
$$

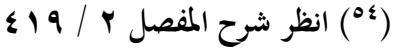

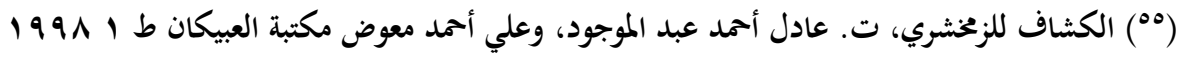

$$
\text { AV T إن }
$$

$$
79 \text { ( } 97
$$

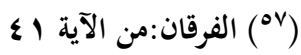

$$
\text { ( }
$$

$$
\text { VYA / Y : انظر مغني اللبيب (\$9) }
$$

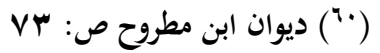$$
\text { (") }
$$

$$
\text { (r) ديوان ابن مطروح ص: DV }
$$$$
\text { ("آ) الأعراف من الآية } 101
$$

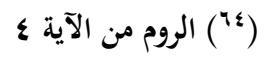




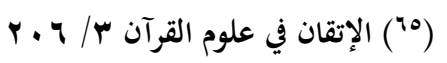

(") (") ديوان ابن مطروح ص: 1؟

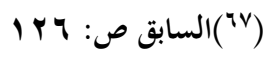

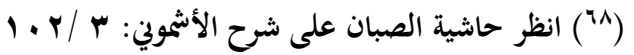

(99) (79) ديوان ابن مطروح ص: 9ه

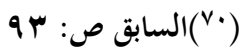

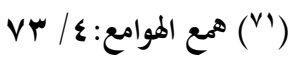

( )

(الانشقاق: 1 (Vu

1 : التكوير (1/2)

$$
\text { IVY النساء: (Vo) }
$$$$
\text { (... الإسراء: من الآية }
$$

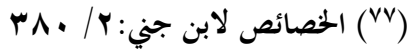

( ديوان ابن مطروح ص: بهa، البهار: زهر طيب الرائحة يميل إلى الصفرة

(1) ( السابق ص: (1)

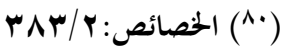

(^)

( السابق ص: (^) 
( ) انظر أسرار العربية لابن الأنباري ت . محمد بججة البيطار، مطبوعات البجمع العلمي العربي بدمشق د

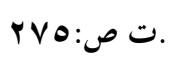

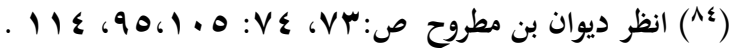

$$
\text { V }
$$

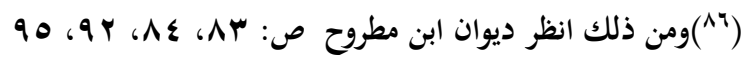

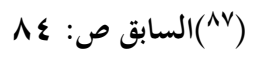

$$
\text { ( }
$$

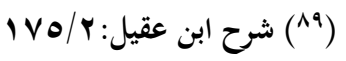

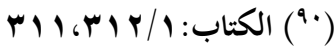

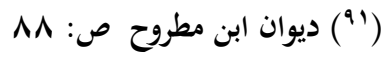

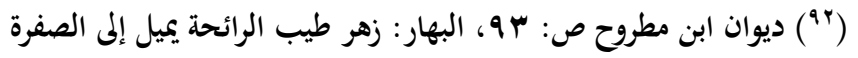

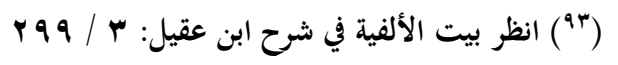

$$
\text { ( } 191 \text { (9) ديوان ابن مطروح ص: }
$$

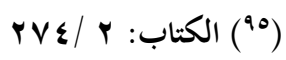

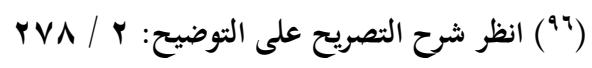

$$
\text { ( }
$$

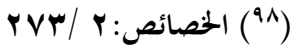$$
\text { ( }
$$

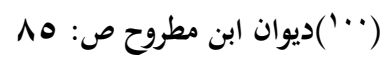

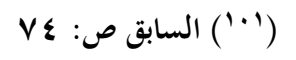




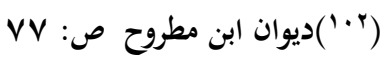

$$
\begin{aligned}
& \text { (ץ+') السابق ص: זي }
\end{aligned}
$$

$$
\text { ( ؛ ' ('ديوان ابن مطروح ص: } 197
$$

(1.0) انظر الإنصاف في مسائل الملاف:ب / צ 4 ؛ وما بعدها

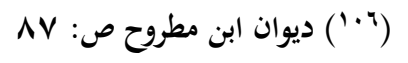

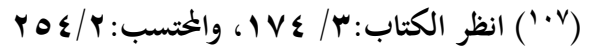

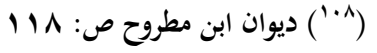

$$
\begin{aligned}
& \text { (1.99) السابق ص: } 194 \\
& \text { |" (") السابق ص:IVA) } \\
& \text { ("') (") }
\end{aligned}
$$

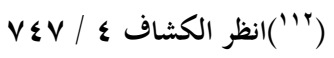

$$
\begin{aligned}
& \text { ("'") ديوان ابن مطروح ص: } 101
\end{aligned}
$$

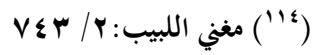

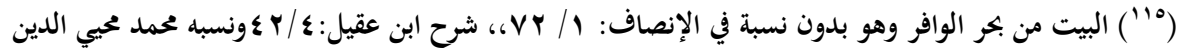

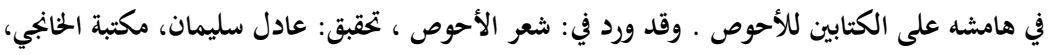

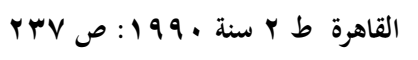

$$
\begin{aligned}
& \text { ("'") ديوان ابن مطروح ص: Ir }
\end{aligned}
$$

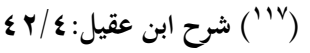$$
\text { ("^) (") ديوان ابن مطروح ص: } 19
$$

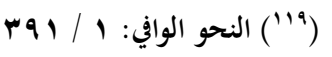

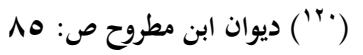

